\title{
GEOPHYSICAL SIGNATURE OF THE DEEP LITHOSPHERE UNDERLYING THE ALTO PARANAÍBA IGNEOUS PROVINCE: CONSTRAINING UPPER MANTLE PROPERTIES
}

\author{
MAURÍCIO DE SOUZA BOLOGNA, ANTONIO LOPES PADILHA \& ÍCARO VITORELLO ${ }^{1}$
}

\begin{abstract}
Magnetotelluric (MT) soundings are presented for the region of Alto Paranaíba Igneous Province (APIP), a complex and economically important Cretaceous magmatic province in western Minas Gerais state. In addition to conventional wideband soundings, suitable for crustal scale investigations, long-period MT was used for the first time in Brazil to investigate the mantle lithosphere. This paper is focused on the interpretation of the long period data, which probe the conductivity structure of the upper mantle between $40 \mathrm{~km}$ and $250 \mathrm{~km}$. The data have included selected sites across the entire APIP, in a 180-km long SW-NE profile. The results show a heterogeneous mantle, in terms of electrical properties, more conductive at depths below $80 \mathrm{~km}$ beneath the borders of both Paraná and Sanfranciscana basins and resistive to depths down to $160 \mathrm{~km}$ in the central part of the profile, over the Brasília fold-thrust belt. Such variations in the conductivity profile of the upper mantle are seemingly compatible with the tectonic evolution of the APIP, developed in the foldbelt and adjacent two sub-basins (Uberaba and Abaeté) with Cretaceous uplift in the central part and subsidence in the sub-basins. The electrical mantle heterogeneity from 80 to $160 \mathrm{~km}$ appears to be in agreement with the petrochemical data, which suggest that the mafic-potassic associations originated at distinct depths from heterogeneous upper mantle sources. Consequently, magmatisms of kamafugitic and carbonatitic affinities would occur in regions coincidental with enhanced conductivities at shallower upper mantle depths, whereas the ones of kimberlitic and lamproitic affinities would occur in regions with deep resistive keels. The geophysical signature corroborates the idea of a patchwork lithosphere composed by older continentil blocks merged with younger blocks during continental convergence. Therefore, a new approach in diamond exploration requires the re-evaluation by deep probing geophysical methods, such as MT deep soundings, of tectonically younger regions that might have accommodated ancient fragments.
\end{abstract}

Keywords: Alto Paranaíba, igneous province, upper mantle, electrical conductivity, magnetotelluric geophysical method.

INTRODUCTION The abundance and variety of volcanic rocks of deep origin erupted in the Alto Paranaíba Igneous Province (APIP), amply studied by petrology, geochemistry, geothermobarometry, trace-elements and isotopes, provide a rare opportunity to examine the full potential of deep-probes to constrain geophysical properties of the mantle that are complementary to the geological information obtained by other means.

In spite of its high potential for the occurrence of economical mineral deposits, the APIP region is poorly known in terms of its geophysical properties at great depths. In this paper we describe the first results of a deep geophysical study in the area using the magnetotelluric (MT) method. The data were analyzed, modeled and interpreted using the most current MT processing and inversion techniques. As the method is particularly sensitive to the detection of any laterally connected conductive medium, the final two-dimensional (2D) conductivity model derived from this study provides a means of identifying the current physical state of the upper mantle and the relationship between distinct electrical conduction mechanisms and mantle petrogenesis.

GEOLOGICAL SETTING The study area is comprised by the Neoproterozoic southern Brasilia fold-thrust belt saddled in the highlands of the Alto Paranaíba between the southwestern margin of the Sanfranciscana basin and the northeastern border of the Paraná basin (Fig. 1).

The foldbelt consists of thin-skinned thrusts with main vergence roughly to the east onto the margin of the São Francisco Craton during the Brasiliano orogeny, as a result of convergence and collision of Precambrian continental blocks. In the study area, the belt is represented by outcrops of metasedimentary rocks and granitoids of the Araxá, Ibiá and Canastra Groups. To the east and center-north, the area is

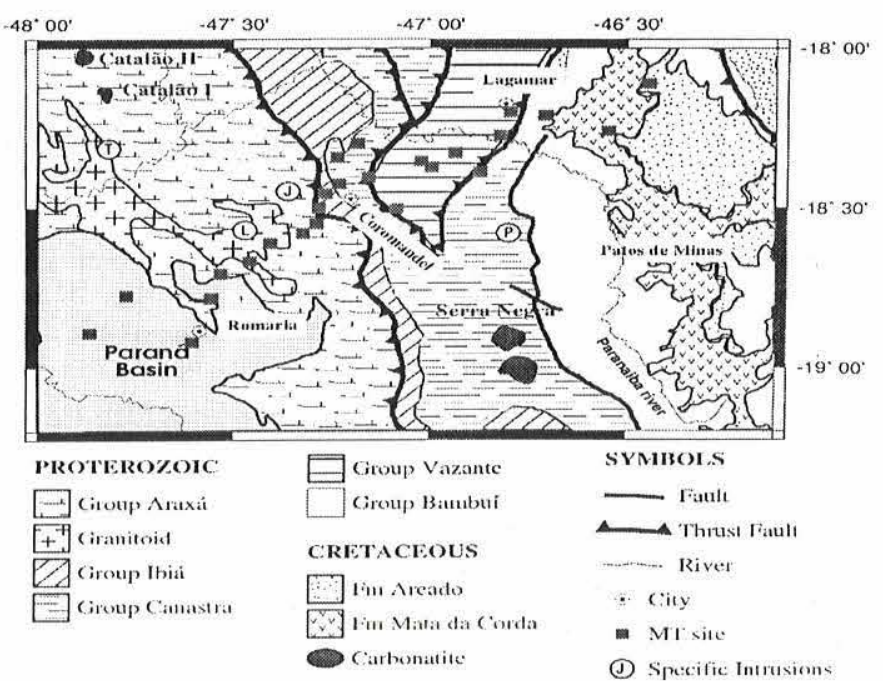

Figure I - Sites of MT soundings plotted in a simplified geological map modified from Schobbenhaus et al. 1981. The encircled letters represent the location of the following diatremes: $L$ - Limeira; J-Japecanga; P - Pântano; PO Presidente Olegario; CP - Carmo do Paranaíba.

covered by metapelites and carbonates of the Bambuí and Vazante Groups, respectively. Siliciclastic and volcanoclastic Cretaceous sediments are found in the southeastern corner (Bauru Group) and eastern portion (Mata da Corda and Areado formations).

Large Cretaceous alkaline complexes occur to the northwest (Catalão I and Catalão II) and southeast (Serra Negra and Salitre) of the area. Cretaceous diatremes, concentrated in and around the central region, are composed by rocks of kimberlitic

I Instituto Nacional de Pesquisas Espaciais - INPE - Caixa Postal 515 - 12201-970 São José dos Campos, SP, e-mail: bologna@ dge.inpe.br, padilha@ dge.inpe.br, icaro@dge.inpe.br 
and lamproitic affiliations, whereas kamafugitic associations predominantly occur in and around the sedimentary rocks of the Mata da Corda (Minas Gerais) and at the border of the Paraná basin, in Rio Verde (southern Goiás).

GEOPHYSICAL DATA The MT method uses natural time-varying electromagnetic fields due to solar activity and electric storms to investigate the electrical conductivity structure of the earth. Two horizontal components of the electric field and three orthogonal components of the magnetic field are simultaneously recorded at the earth's surface over a large range of frequency. The horizontal electric and magnetic fields are related through transfer functions (impedance) used to calculate apparent resistivities and phases as functions of the measured frequencies. In another approach, two complex transfer functions relating the vertical and horizontal components of the magnetic field are also derived. They are represented by real and imaginary induction arrows, which are used as a mapping tool for locating regional anomalous structures.

Plots of apparent resistivity and phase against frequency are the main results of a MT sounding at a given site. These plots resemble a highly smoothed electrical $\log$ with an axis of frequency rather than depth. The information concerning the depth is obtained thanks to the skin-depth effect, which implies that the electromagnetic wave amplitude decays as it diffuses down through the earth depending on the frequency of the wave and the subsurface conductivity. The geological structures responsible for the MT curves are determined from comparisons of the experimental data with synthetic data computed from models. The state-of-the-art of the MT method up to the early 1990's has been presented by Vozoff (1991).

This study consists of a roughly SW-NE profile crossing the cluster of diatremes, along the towns of Romaria, Monte Carmelo, Coromandel and Lagamar (see locations of MT sites in Fig. 1). The northeastern limit of the profile lies on the Alto Sanfranciscana basin (Abaeté sub-basin), whereas the southwestern limit falls on the Paraná basin (Uberaba sub-basin). Two different types of MT recording systems were used to cover a broad period range providing a resolution from very shallow to very large depths. The first instrument is a fivecomponent broadband system commercialized by Metronix $\mathrm{GmbH}$ (Germany). It was used in all sites and covered the period range from 0.001 to $1000 \mathrm{~s}$. At some selected sites, a new generation, high-sensitivity, ring-core fluxgate-based system developed in recent years by the Geological Survey of Canada and commercialized by Phoenix Geophysics Ltd. (Canada) was used by the first time in Brazil. The sampling interval of these systems was $5 \mathrm{~s}$, with a recording duration of typically 8 to 10 days, allowing the analysis of data in a period from 20 to $14,000 \mathrm{~s}$. At these sites, the complete MT response functions spanned the period range from 0.001 to $14,000 \mathrm{~s}$.

Modern techniques of robust data processing were applied to estimate the MT tensor response functions (see detailed description in Bologna 2001). Figure 2 shows examples of original sounding data at two sites, one at the southwestern part of the profile (site 008, directly over Paraná basin sediments) and the other close to the center of the profile (site 112, over the phyllites and quatzites of the Canastra Group in the Brasilia fold-thrust belt). Open and solid symbols denote the results from the two different MT systems used, respectively the broadband and long-period, estimated for both orthogonal directions.

Apart from larger error bars at the longest periods,
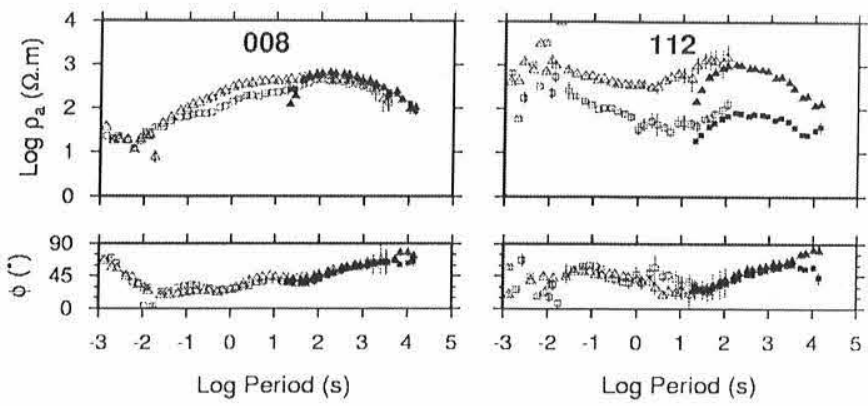

Figure 2-Examples of two contrasting MT soundings for one site over sediments of the Paraná Basin (site 008) and another over crystalline rocks of the Canastra Group (Site 112). The upper diagram corresponds to apparent resistivities and the lower diagram to phases, both as a function of the measured period, compiled from the broad-band (open symbols) and the long-period equipment (solid symbols). Error bars are one standard deviation.

attributed to the limited recording time at these periods and the lack of geomagnetic activity during data collection, the data at site 008 are of excellent quality. Also, the parallel and perpendicular apparent resistivities and phases are almost identical along the whole period range, indicative of one-dimensional structure (conductivity varying with depth only) to larger depths. On the other hand, site 112 is typical of soundings carried out directly over resistive metamorphic rocks of the Brasilia belt. Especially at shorter periods, data quality is less satisfactory because these sites are more severely disturbed by cultural noise that propagates to larger distances facilitated by the resistive terrains. Large separations in apparent resistivity along most of the period range, with the variations in phase nearly identical in the two orthogonal directions, are taken as a qualitative indicator of galvanic distortions affecting the apparent resistivity results. Also, a separation in phase is clearly seen at periods around $10 \mathrm{~s}$, indicative of an anisotropic layer in the middle-to-lower crust. At the longest periods, in both sites (penetrating into the deep lithosphere), apparent resistivities are seen to decrease nearly monotonically with increasing periods, and phases are generally greater than $45^{\circ}$. This result indicates that the conductivity increases in the mantle in pace with increasing depths.

Distortion analysis was also applied to the MT response estimates to determine the dimensionality of the data, derive the regional 2D electric strike direction, and remove the effects of galvanic scatters (Groom \& Bailey 1989, McNeice \& Jones 2001). The analysis indicated a very complex geoelectric region including the presence of distinct electrical anomalies, affected by three-dimensional (3D) induction effects and galvanic distortions due to shallow structures, anisotropy at intermediate crustal depths, azimuthal variations of the anisotropy along the profile, galvanic distortions in long periods due to crustal anisotropy, and variations of the electrical strike along distance and with depth. Based on these results, it was decided to analyze separately data of short periods and data of long periods. Data separation was done at the period of $53 \mathrm{~s}$ because at this period the estimated inductive scale is of the same order of the crustal thickness of the study area $(40 \mathrm{~km}$ approximately, Assumpção et cal. 1997).

In this paper, we will restrict the analyses to the data of the long period (from 53 to $14,000 \mathrm{~s}$ ), with penetration in the 
upper mantle. In this period range, the distortion models fit the data well, which implies that a 2D description of regional structures is a reasonable assumption, and most sites display a period-independent preference for a strike around $\mathrm{N} 45^{\circ} \mathrm{E}$. Accordingly, distortion models were fit to the data with that assumed strike direction, with the electrical current flowing along the strike direction defining the TE mode while the perpendicular responses define the TM mode.

\section{RESULTS AND DISCUSSION 2D inversions were} performed on the decomposed regional data. Joint and independent inversions of the TE and TM modes were undertaken, but here we report only the joint inversion of both datasets. The rapid-relaxation inversion algorithm of Smith \& Booker (1991) was used because this code seeks the smoothest model, in terms of least variation of conductivity both laterally and vertically, which fits the data. To avoid effects of static shift, only the phase data were fit in the inversion and a $3 \%$ error floor was assumed to account for "geological noise". As discussed previously, the long-period data are insensitive to structures at depths shallower than roughly $40 \mathrm{~km}$. An initial model was therefore derived from the inversion of the shortperiod data (Bologna 2001) and shallow structures (less than $40 \mathrm{~km}$ ) were constrained to vary little laterally and with depth. At larger depths, a $100 \mathrm{ohm} . \mathrm{m}$ half space was used.

The final 2D conductivity model is presented in Figure 3. The robustness of this model was tested in different inversions, by adding and removing stations, changing the inversion parameters and using a different inversion code (Siripunvarapon \& Egbert 2000). The main features presented in Figure 3 were, however, required to fit the data.

In general, the results indicate a lithosphere with an overall conductivity much more intense than what is inferred from a dry olivine-rich upper mantle, such as for instance in the Archean Superior craton, Canada (Schultz et al. 1993).

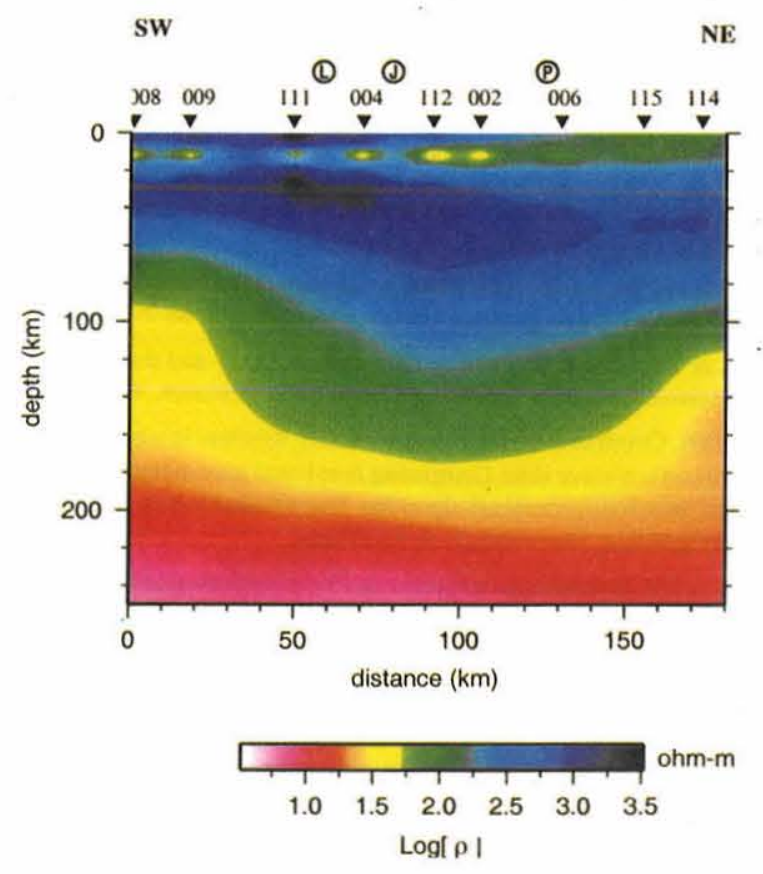

Figure $3-2 D$ resistivity (inverse of conductivity) model estimated from the simultaneous inversion of the TM and TE modes of the projected MT sites into a SW-NE profile. The site number and diatremes location are shown at the top.
Nevertheless, the estimated APIP conductivity is of similar magnitude to values from the Basin and Range, USA, oceanic setting (Lizarralde et al. 1995) and even the Archean Churchill craton, Canada (Boerner et al. 1999).

However, the most conspicuous result of the APIP model is the identification of a more resistive region at shallower upper mantle depths that becomes more conducting at greater depths. This general trend is in agreement with the expected increase by thermally activated solid-state conduction in upper mantle minerals. Yet, the transition to stronger conductivity is observed at greater depths in the center of the profile, beneath the APIP (for reference, the town of Coromandel is placed between the stations 004 and 112). Thus, the MT data show that the upper mantle is laterally much more heterogeneous, in terms of electrical properties, at depths from 80 to $180 \mathrm{~km}$ approximately, being more conductive under the Paraná basin (stations 008 and 009) and Abaeté sub-basin (stations 115 and 114) than in the resistive central region, beneath the outcrops of the foldbelt.

There is a striking spatial correlation of the upper mantle conductivity with the mafic-potassic magmatism. Rocks of kamafugitic affinities tend to occur in regions (Mata da Corda, Paraná basin) coincident with enhanced conductivity at shallower upper mantle depths, whereas the kimbelitic and lamproitic associations occur in regions with deep resistive keels. Regions beneath carbonatites could also be underlain by anomalous conductivity because of the close mantle source association between carbonatites and kamafugites (Brod et al. 2000). Carbonatite-kamafugite melts, rich in clinopyroxene, would take place at pressures around $25 \mathrm{kbar}$ (Moore \& Wood 1998) which would correspond to the strong transition in mantle conductivity (resistivity drop from $600-500 \mathrm{ohm} . \mathrm{m}$ to 100-50 ohm.m in Fig. 3).

The likely factors that could account for the enhanced conductivity at such shallower upper mantle depths are firec conductive fluids, hydrated minerals, graphite and metallic sulphides (Jones 1999; Jones et al. 2001). The preference would be for the former, since there is no evidence of hydrated minerals associated with xenoliths and the oxidation environment is probably too high for the last two (Haggerty 1986, Alard et al. 2000). Furthermore, an effective flow of current requires the preservation of an interconnected conducting phase network through time, not to be disturbed by subsequent events. Kimberlite melts, depleted in clino-pyroxene, would also occur at the same transition but at deeper levels, around 140-160 km, such as in the Três Ranchos kimberlite (Leonardos et al. 1993), probably within the diamond stability field.

Comparing the APIP result with available geophysical information from peripheral regions of the study area (heat flow, Vitorello et al. 1980; gravity, Ussami 1999; seismic, Snoke 2001); it is observed that the sharp transition from more resistive (600-500 ohm.m) to more conductive values (100-50 ohm.m) at depths between 80 and $140 \mathrm{~km}$ is too shallow to be attributed to the lithosphere-asthenosphere boundary. One possible interpretation of the conductivity model is that the top of the geoelectric-asthenosphere would be around $200-220 \mathrm{~km}$ (resistivity less than $30 \mathrm{ohm} . \mathrm{m}$ ), because at these deep levels, conductivity could be enhanced by interconnected partial melt phases and hydrogen diffusion (Karato 1990). Yet, at depths below $200 \mathrm{~km}$ our data are much less reliable.

CONCLUSIONS The 2D conductivity model for the deep lithosphere obtained in this work indicates a resistive deep keel 
underneath the center of the APIP, surrounded by more conductive mantle material below $80 \mathrm{~km}$ depths. Such heterogeneity is consistent with petrochemical data, which suggest that the mafic potassic intrusions formed after an heterogeneous source at distinct depths in the upper mantle. Also, the temperature of crystallization of the Mata da Corda kamafugitic magmas (Sgarbi et al. 1998) and the thermobarometry of the Três Ranchos (Leonardos et al. 1993) intrusion imply the occurrence of contrasting paleo-geotherms between the colder central part of the APIP and the warmer adjacent region where the Mata da Corda and Paraná basin occur. Accordingly, the high resistivity in the central deep keel of the model must generically be associated with a colder and/or dehydrated lithosphere. A possible interpretation suggests the presence of ancient continental fragments caught up in the Brasilia foldbelt during the convergence of colliding continents, as indicated from evidences from several studies (Pimentel \& Fuck 1992, Bizzi et al. 1995, Carvalho 1997, Araujo 2000). The observed ano-malous conductivity could be ascribed to metasomatic mecha-nisms (increased free fluids, volatiles, temperature, and oxygen fugacity) as suggested in several other regions such as in the Churchill Craton (Boerner et al. 1999).

From this discussion, it can be concluded that the undulation at the base of the resistive layer of the geolectrical model of Figure 3 (depths of about $80 \mathrm{~km}$ in the southwest, 160 $\mathrm{km}$ in the central part, and $100 \mathrm{~km}$ in the northeast of the profile) seems to be correlated to structures inherited from the past and yet possibly affected by the Cretaceous events. These events have left lingering residues in the upper mantle, which exert important control in the propagation of the clectromagnetic signal at long periods. Such relationship indicates the potential of MT deep soundings to probe the lithosphere underneath thick allochthonous overthrust in search of hidden ancient fragments, hosts of a diamond stability field, and opens up the possibility of re-evaluation of younger tectonic terrains for primary diamond sources.

Acknowledgements Grants from FAPESP (proc. 95/0687-4 and 00/00806-5) and fellowships from CNPq (142617/97-0, 351398/94-5 and 350683/94-8) supported this study. Logistical support from Sopemi S.A. is also acknowledged.

\section{References}

Alard O., Griffin W.L., Lorand J.P., Jackson S.E., O'Reilly S.Y. 2000. Nonchondritic distribution of the highly siderophile elements in mantle sulphides. Nature, 407:891-894.

Araujo A.L.N. 2000. Petrologia dos pipes kimberlíticos e kamafugíticos da província alcalina do Alto Paranaíba, Minas Gerais e Goiás. Universidade de Brasilia, Brasilia. Tese de Doutoramento.

Assumpção M., James D., Snoke J. 1997. Crustal thickness in SE shield with receiver functions: isostatic compensation by density variations in the lithospheric mantle? In: SBGf, International Congress of the Brazilian Geophysical Society, 5, São Paulo, Resumos Expandidos, 2:895-897.

Bizzi L.A., deWit M.J., Smith C.B., McDonald I., Armstrong R.A. 1995 Heterogeneous enriched mantle materials and Dupal-type magmatism along the SW margin of the São Francisco craton, Brazil. Journal of Geodynamics, 20:469-491.

Boerner D.E., Kurtz R.D., Craven J.A., Ross G.M., Jones F.W., Davis W.J. 1999. Electrical conductivity in the Precambrian lithosphere of Western Canada. Science, 283:668-670.

Bologna M.S. 2001. Investigação Magnetotelúrica da Litosfera na Província Ígnea do Alto Paranaíba. INPE, São José dos Campos, Tese de Doutoramento, $219 \mathrm{p}$.

Brod F.A., Gibson S.A., Thompson R.N., Junqueira-Brod T.C., Seer H.J., Moraes L.C., Boaventura G.R. 2000. The kamafugite-carbonatite association in the Alto Paranaíba Igneous Province (APIP) southeasten Brazil. Revista Brasileira de Geociências, 30:404-408.

Carvalho J.B. 1997. Petrologia de xenólitos mantélicos da província do Alto Paranaíba, Minas Gerais. Universidade de Brasilia, Brasilia, Tese de Doutoramento.

Groom R.W. \& Bailey R.C. 1989. Decomposition of magnetotelluric impedance tensor in the presence of local three-dimensional galvanic distortion. Journal of Geophysical Research, 94:1913-1925.

Haggerty S.E. 1986. Diamond genesis in a multiply-constrained model. Nature, 320:34-38.

Jones A.G. 1999. Imaging the continental upper mantle using electromagnetic methods. Lithos, 48:57-80).

Jones A.G., Ferguson I.J., Chave A.D., Evans R.L., McNeice G.W. 2()()1. Electric lithosphere of the Slave craton. Geology, 29:423-426.

Karato S. 1990. The role of hydrogen in the electrical conductivity of the upper mantle. Nature, 347:272-273.

Leonardos O.H., Carvalho J.B., Tallarico F.H.B., Gibson S.A., Thompson R.N., Meyer H.O.A., Dicken A.P. 1993. O xenólito de granada lherzolito de Três Ranchos: Uma rocha matriz do diamante na Província Magmática Cretácea do Alto Paranaíba, Goiás. In: SBG, Simpósio Brasileiro de Geologia do Diamante, 1, Cuiabá, Anais, 228 p.

Lizarralde D., Chave A.D., Hirth G., Schultz A. 1995. Northeastern Pacific mantle conductivity profile from long-period magnetotelluric sounding using Hawaii to California submarine cable data. Journal of Geophysical Research, 100:17837-178.54.

McNeice G.W. \& Jones A.G. 2001. Multisite, multifrequency tensor decomposition of magnetotelluric data. Geophysics, 66:158-173.

Moore K.R \& Wood B.J. 1998. The transition from carbonate to silicate melts in the CaO-MgO-SiO2-CO2 system. Journal of Petrology, 39:1943-1951.

Pimentel M.M. \& Fuck R.A. 1992. Neoproterozoic crustal accretion in central Brazil. Geology, 20:375-379.

Schobbenhaus C., Campos D.A., Derze G.R., Asmus H.E. 1981. Mapa Geológico do Brasil e da área adjacente, incluindo depósitos minerais, escala 1:2.500.000. Brasília: DNPM/MME. (4 folhas).

Schultz A., Kurtz R.D., Chave A.D., Jones A.G. 1993. Conductivity discontinuities in the upper mantle beneath a stable craton. Geophysical Research Letters, 20:2941-2944.

Sgarbi P.B.A., Clayton R.N., Mayeda T.K., Gaspar J.C. 1998. Oxygen isotope thermometry of Brazilian potassic volcanic rocks of kamafugitic affinities. Chemical Geology, 146:115-126.

Siripunvaraporn W. \& Egbert G. 2000. An efficient data-subspace inversion for two-dimensional magnetotelluric data. Geophysics, 65:791-803.

Smith J.T. \& Booker J.R. 1991. Rapid inversion of two- and three-dimensional magnetotelluric data. Journal of Geophysical Research, 96:3905-3922.

Snoke J. 2001. Constraints on the S-wave velocity structure in a continental shield from surface-wave data: Comparing non-linear least-squares inversion and direct-search neighborhood algorithm. Unpublished report, Inst. Astronômico e Geofísico, Universidade de São Paulo.

Ussami N. 1999. Estruturação e limites da Placa Sanfranciscana: Contribuição gravimétrica. Inst. Astronômico e Geofísico, Universidade de São Paulo, São Paulo, Tese de Livre Docência, 24 p.

Vitorello I., Hamza V.M., Pollack H.N. 1980. Terrestrial heat flow in the Brazilian highlands. Journal of Geophysical Research, 85:3778-3788.

Vozoff K. 1991. The magnetotelluric method. In: Nabighian, E. (ed.), Electromagnetic methods in Applied Geophysics. Tulsa, Society of Exploration Geophysics, 641-711.

Manuscrito A-1292

Recebido em 19 de novembro de 2001

Revisão dos autores em 03 de dezembro de 2001 Revisão accita em 05 de dezembro de 2001 